\title{
Conservation and management of sacred groves, myths and beliefs of tribal communities: a case study from north-India
}

\author{
Laxman Singh Kandari ${ }^{i^{*}}$, Vinod Kumar Bisht ${ }^{2}$, Meenakshi Bhardwaj ${ }^{3}$ and Ashok Kumar Thakur ${ }^{4}$
}

\begin{abstract}
Background: Traditional and indigenous communities in India are of the religious belief that medicinal groves and plants are sacred in nature. Sacred groves (SGs) are patches of trees on forest land that are protected communally with religious zeal and connotations. These forest areas have been protected since ages by traditional societies and indigenous communities with their socio-cultural and religious practices. Sacred groves as a rule are treated piously. Sacred trees are prohibited from cutting and not axed except when wood is needed for the religious purposes like construction and repair of temple buildings or in cases like worshiping, death ceremonies and temple rituals. Thus, SGs carry direct and everlasting pious status and assist in maintaining social fabric of the society.

Results: From the present study it is concluded that, religious identification of medicinal plants and practices have influenced the folklore towards a sense of selfless services in the name the Gods. However, during the course of modernization, mechanization and globalization in the recent past has transformed and weakened both cultural and biological integrity. Changes in social belief, modernization and erosion of cultural practices are some of the major factors contributing towards degradation of the ancient institutional heritage which need to be looked into.
\end{abstract}

Conclusion: The present study is, therefore intended to propose management and conservation as an alternative strategy towards the sustainability of forests around human settlements and also an attempt to explore the role of SGs in conservation and management of different ecosystem services.

Keywords: Conservation; Ecosystem services; Sacred groves; Sustainability; Traditional

\section{Background}

India is among the 12 mega biodiversity countries in the world having 25 hot spots of the richest and highly endangered eco-region of the world (Myers et al. 2000). Due to increasing pressure of population, degradation and depletion of forests, it remains a challenging task to manage forests in a sustainable manner. India is classified under one of the low forest cover countries and account for $23.8 \%$ of total geographical area of the country (FSI Forest Survey of India 2005). This percentage is still low as highlighted in the Forest Policy (1988). There are about 0.63 million villages (Rehmani 2012), out of which

\footnotetext{
* Correspondence: luxkandari@gmail.com

'School of Natural Resource Management and Environmental Sciences, College of Agriculture and Environmental Sciences, Haramaya University, P.O. Box \# 337, Dire Dawa, Ethiopia

Full list of author information is available at the end of the article
}

nearly one-third are in the vicinity of forests. Thus, quite a large population is traditionally dependent on forests for a variety of reasons such as food, shelter, fodder, timber, and medicine which are directly linked to livelihood of these societies. Conservation of natural resources including biodiversity has been an integral part of several indigenous communities in and around the forest areas. The concept of sacred groves is very old and has existed since the time of Rig-Veda (an ancient Indian sacred collection of Vedic Sanskrit hymns), when tree worship was quite popular and universal. Buddha's study and enlightenment was also in the company of a banyan tree (Negi 2005). The concept and beliefs of sacred trees and groves of forests are one of the best practices to conserve the natural resources. Sacred groves (SGs) are small forest areas that are left untouched by the local inhabitants to be con- 
served by the local village folk deities and are of special spiritual significance to them (Figure 1). Sacred groves, also known as church forests, fetish forests and sacred forests, are found all over the world including Ethiopia, Japan, Morocco, India, and Ghana (Cardelús et al. 2013). The concept of SGs has been a part of rich traditional and diverse culture of Indian societies for many generations. Sometimes, they are also known as natural museums of giant trees, treasure houses of threatened species, dispensaries of medicinal plants, regulators of water sheds, recreation centers for urban life, veritable gardens for botanists, gene banks of economic species, paradise for nature-lovers and laboratory for environmentalists (Bhagwat 2009; Manikandan et al. 2011). Interestingly, they are found worldwide in all part of different continents i.e. Africa, Asia, Europe, Australia and America (Hughes and Chandran 1997). Around 1,00,000 to 1, 50,000 sacred groves are reported in India (Malhotra et al. 2007). In India the highest number of SGs (5000) has been reported to be present in state of Himachal Pradesh followed by Kerala and Chhattisgarh. Different scientific reports revealed that these SGs can support and conserve different fauna and flora (Khan and Tripathi 2004; Chandran et al. 1998; Sukumaran and Jeeva 2008; Ray and Ramachandra 2010; Singh et al. 2010). Indian ancestors were fully aware about that the importance and significance of natural resources that sustained them which were necessary to be conserved for the sustenance of future generations. They lived in harmony with nature and thereby played an important role in conservation of biodiversity.

In India, different religions having different traditions, beliefs, and rituals are associated with conservation of biodiversity and forests. In Hindu religion, it is a traditional belief that nature shows a reverence for five basic elements i.e., Earth (Prithvi), Fire (Agni), Water (Jal), Air (Wayo) and Space (Akash). All the five elements are treated as a body of God and are worshipped. These five elements are protected for religious, cultural and spiritual reasons. There are many studies entitled to further quantify this ethics, which leads to biodiversity conservation and sustainable ecosystem (Pal and Mukhopadhyay 2011).

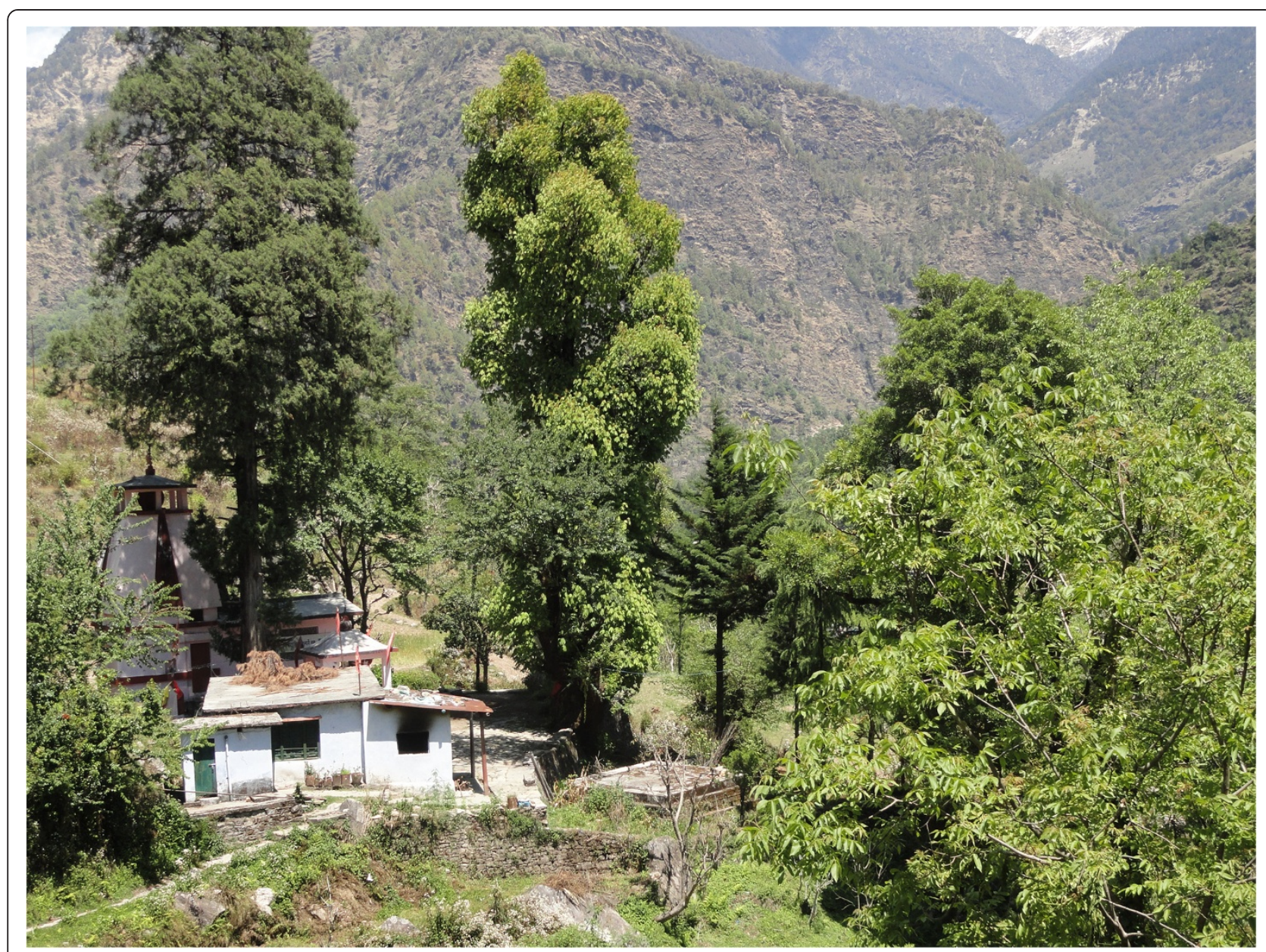

Figure 1 Sacred trees around temple. 
The SGs play an important role in ecosystem services such as clean environment i.e., air, soil and water conservation, flora and fauna conservation, carbon sequestration, temperature control and conservation of traditional knowledge. They are therefore, the epicenter of ecological conservation research and policy regarding conservation and management of forest at state and national levels (Ray and Ramachandra 2010). There are several studies carried out by various researchers on this subject highlighting significant role and potential of the SGs. The present paper therefore, explores the role of SGs in conservation and management of different ecosystem services in Indian society.

\section{Results and discussion}

\section{Taboos for plant and animal conservation}

From the current study it was found that, in Chamoli district of Uttarakhand state (India), people believed that when a village rural girl gets married, the married couple has to plant a seedling of a tree in bride's house. Planting a tree seedling is a cultural and traditional practice in this region which later gained momentum in late eighties and succeeded in creating a lot of awareness among the locals. Planting of sapling as a marks of respect, is undertaken by VIPs during their visit to various establishments. This practice has been popular and planting a tree seedling has been taken up by non-government organizations (NGOs) as an important movement (Maiti Andolan) which includes list of taboos that slowly intensified, spreading to nearby areas of the region. This is a new and novel approach for biodiversity conservation in the hilly region through plantation, where the occurrence of land slide and natural hazards are more frequent. Another example of such conservation is the alpine plants Saussurea obvallata and Delphinium vestitum locally called Dongar and Loshkar; which have been protected through local customs and beliefs by linking these plants with local deity and not allowing any one from the village or outside to pluck the flowers except the village priest during specific day and time only (Meenakshi et al. 2011).

Taboos are the unwritten, orally transmitted traditional and social rules that regulate human behavior (Colding and Folke 1997; Banjo et al. 2006). In rural areas of India, many plants and animals are considered as pious and sacred religiously having imbibed cultural values among the tribal communities. The religious belief serves as an instrument of protection of those rare forest species (Pandey 2003).

\section{Approach towards Eco-retreats}

The devastating impact of pollution, supplemented by deforestation can only be restored by green lung area of the sacred groves which, besides providing numerous tangible products remains the storehouse of the life gasoxygen. If these storehouses are not properly managed and conserved, the future generation will definitely be deprived off this valuable asset (Anthwal et al. 2006). As a part of school curriculum, school children are often asked to plant saplings in school compounds to understand the importance of trees. Planting for the progamme are supplied by the local forest department for this purpose. Saplings of the plants like sandal (Santalum album) are specially planted in lower areas, which have specially seen the severest cutting and elimination out of greed.

\section{Belief and myth towards soil and water conservation}

Sacred groves play an important role in soil and water conservation. They improve the soil stability of the region and act as soil binder. Plants like vetiver grass (Vetiveria zizanioides) and Eucalyptus spp are maintained to bind the soil thereby preventing soil erosion. In India, water of different rivers are treated as holy among all sources and used in all rituals and worships. People take holy dip/bath at the confluence of two or three rivers called prayag or sangam (meaning union) in different parts of the country i.e., Devparyag, Allahabad, Nasik etc. As most of the cities and town are settled on the bank of rivers ie., Ganga, Yamuna, Brahmaputra, Godavari, Krishna, Kaveri, etc. which are, not only considered sacred but are also a source of drinking water supply cities in the country. Small natural water bodies are maintained, near SGs to take care of drinking water problem during drought. Villagers are now improving the surrounding areas of water bodies with concrete structure to conserve natural flowing Waterbodies and maintain it in a hygienic condition.

\section{Approach towards Carbon sequestration}

Estimation of carbon stocks and stock changes in tree biomass are necessary for reporting to the United Nations Framework Convention on Climate Change (UNFCCC) and which is required for Kyoto Protocol reporting also. Very little work has been done so far for estimation of the carbon sequestration potential of the sacred groves except for few reports, where carbon sequestration potential of various species was estimated in Maharashtra (Hangarge et al. 2012). The tree, Terminalia bellirica was found to be dominant of sequestrating 327.78 tonnes of carbon followed 221 tonnes by Ficus amplissima (Hangarge et al. 2012). The species Gnidia glauca had lowest carbon sequestration potential i.e. 0.0808 tonnes. A SGs having thick vegetation possesses high carbon sequestration potential thereby contributing to reduced concentration of $\mathrm{CO}_{2}$ in the atmosphere (Hangarge et al. 2012).

Traditional knowledge for conservation and management Traditional societies are characterized by their close interconnection with nature and its resources. Hence, the traditional communities depend upon natural resources and 
biodiversity more for their livelihood (Ramakrishnan 1996). Even now the NGOs working in the region make it a point to plant important utility plants like soap nut (Sapindus mukorossi), arjun (Terminalia arjuna) Roxb., sandal (Santalum album) to strengthen the SGs in different lower regions.

\section{Conservation of Medicinal and Aromatic Plants through local belief}

The SGs are believed to be a treasure house of medicinal and aromatic plants. Though most of the indigenous people residing near the groves are illiterate, they have scrupulously nurtured their traditional customs, rituals, ceremonies and a way of forest life through folk beliefs with great vigour. The fact that sanjeevani found in Himalayan region was used by Lord Hanuman (A Hindu deity) to resuscitate Lakshman the brother of Lord Rama is well known to all Indians. There is a need for protection of large number of medicinal plants as an important component of SGs in different parts of India which is already documented in various studies (Vartak et al. 1987; Bhandary and Chandrasekhar 2003; Pandit and Bhakat 2007). In Doonagiri village of Nanda Devi Biosphere Reserve, Uttarakhand state, tribal people of Bhotiya community have an ancient practice of conserving the medicinal plants of the region for centuries. This is mainly attributed to their religious belief. They have deep faith that if someone from outside the village uproots the medicinal plants from their village, it is treated as an evil act which may bring misery of great order to the village folks. They nurture a belief that Lord Hanuman came to their village and uprooted all their medicinal plants which was the cause of untreatable diseases, which struck the people later. Thus, medicinal plant conservation is an integral part of sustainable living by these people with the nature (King-Oliver et al. 1997). Till now medicinal plants like mint (Mentha arvensis), coriander (Coriandrum sativum) and fenugreek (Trigonella foenum-graecum) are planted as an important component of SGs and preserving Himalayan ecosystem.

\section{Approach towards animal conservation}

Almost all Hindu Gods are associated with animals, birds and creatures as their vehicles or vahanas. This concept is to promote harmony in nature to maintain ecosystem. Protection of animals and other creatures along with human beings is essential to maintain ecological balance. As a result, all categories of wild and domesticated animals were identified/attached to Gods (Table 1). For instance, Garuda (eagle) Vahanam (Vah in Sanskrit language means to carry or to transport) was symbolized with Lord Vishnu, Peacock to Muruga, Bull to Lord Shiva, Tiger to goddess Durga and Rat to Vinayaka. Thus, all gods typically or mythologically are symbolized with animals as their vahanas often called the deity mounts. The association of animals with Gods as Vahanams (vehicles) is a deliberate attempt to weave mythology for protection of animals and plants in order to maintain ecological balance. Often, God is icongraphically depicted riding animals as (or simply mounted upon) vahana. Even one of the trees, Kalpavrusha, is treated as vahana. Lord Shiva uses lion skin for his attire and as supports a reptile king cobra as an ornament. Serpents are venerated on Nagpanchami day and offered milk for maintaining the natural food chain and preserving environment of SGs. Monkeys as a part of respect to Lord Hanuman and bears were also treated as gods and remained a part of the army force of Lord Rama (Table 1).

In many traditional Hindu mythological literatures the killing or hurting a cat is a crime which is also sinful and harmful. If any person is involved in killing the cat he has to make a statue of the cat of gold/bronze metal and kept submerged in deep water to get solace and relief from the effects of the committed sin. The scientific reasoning behind the Hindu mythology was that cat kills and eats many insects and rats as an integral part of food chain, thereby preventing the spread of many viral diseases. Hence, cats need to be protected which are human friendly with their livelihood practices. In Rajasthan (western-India), the Bishnoi community treats Black Buck Deer as their child and killing or harming them is considered a great sin. Thus, Bishnoi cult supports the wildlife protection act as Black Buck Deer is considered as human friendly in selected localities (Kala and Sharma 2010). Such incidences are widely prevalent and practiced in other countries also. The cow worship is another example of deep religious belief in India. Cow milk is treated as source of balanced diet for children in the Indian food basket. Cow dung is treated as having anti infection properties and used for domestic purposes. Cow urine is believed to possess rich chemical content and is highly useful to treat disease of human beings and is also applied as pesticide. With all its multidimensional uses of cow products, cows are treated sacred and prohibited from killing and worshipped in the name of Kamadhenu (Table 1).

\section{Conservation of floral diversity}

India is among the few countries where trees or forests are also worshiped during their religious rituals. Majority of plants/trees are accepted as sacred by Hindus and hence worshipped. Sacred groves are the best example of in-situ conservation of biodiversity, where flowers like hibiscus (Hibiscus rosa-sinensis), marigold (Tagetes erecta), jasmine (Jasminum officinale) Brahmakamal (Saussurea obvallata) are found in plenty. These SGs harbour many endemic species some of which are at different threat levels in different regions in the country. The state of Uttarakhand is endowed with world heritage site valley of 
Table 1 List of some common animals, birds \& reptiles and their associated beliefs

\begin{tabular}{|c|c|c|c|}
\hline S. No. & Scientific name & Local name & Beliefs/uses \\
\hline 1 & Panthera tigris & Tiger & Used in rituals and medicine. \\
\hline 2 & $\begin{array}{l}\text { Elephas maximus } \\
\text { indicus }\end{array}$ & Elephant & $\begin{array}{l}\text { In Hindu mythology, during Sagar Manthan (Milk sea churning), the Gods (Angels) and the demons (Asura) } \\
\text { churned the ocean for the elixir of life called "Amrit" (Nectar) which make them immortal. From the churning } \\
\text { the 'navratnas' (nine jewels) surfaced. Some of these jewels were the Aeravatha (white elephant), Karpavruksha } \\
\text { (tree), Kamadhenu (Holy cow). Therefore considered to be sacred among Hindus. }\end{array}$ \\
\hline 3 & Bos Taurus & Cow & $\begin{array}{l}\text { In Hindu mythology the cow is considered holy The cow is equated to one's own mother (hence the } \\
\text { expression 'Gaumata). In Hindu mythology, Kamadhenu, the wish-fulfilling celestial cow. It is believed } \\
\text { that cow could grant any wish for those who worship cow. }\end{array}$ \\
\hline 4 & Bos taurus & Bull & $\begin{array}{l}\text { Bull occupies a special place in Hindu mythology. The reverence of the animal has been one of the } \\
\text { central themes of Hinduism, since ancient times. Bull is vehicle/vahana of lord Shiva. }\end{array}$ \\
\hline 5 & Antilope cervicapra & Black buck & It is also known as Krishna Mruga in Kannada. \\
\hline 6 & Macaca mulatta & Monkey & Monkey is known to be associated in the army of Hindu God Hanuman hence considered sacred. \\
\hline 7 & Felis catus & Cat & Cats are associated with fertility and the goddess of birth, Shakti. \\
\hline 8 & Pavo cristatus & Peacock & $\begin{array}{l}\text { Hindu mythology peacocks are associated with the goddess Saraswati (goddess of education \& knowledge). } \\
\text { The feathers thus represent qualities like: kindness, patience and good fortune. }\end{array}$ \\
\hline 9 & Naja naja & Snake & $\begin{array}{l}\text { The snake is commonly called ('Nag' in Hindi language) is worshipped by people across the country. } \\
\text { Some of the snakes are considered in mythology as 'protectors' and other categories as harmful/ } \\
\text { destroyers'. Lord Shiva wore snake as an ornament. Lord Vishnu sleeps on snake with thousand heads } \\
\text { Adiseshu (King cobra) as his bed on milk sea. }\end{array}$ \\
\hline 10 & Bos grunniens & Yak & The bushy tail is in great demand as a fly-wish (fan) in many Buddhist monasteries and temples. \\
\hline 11 & Gyps indicus & $\begin{array}{l}\text { Indian } \\
\text { Vulture }\end{array}$ & $\begin{array}{l}\text { According to the epic Ramayana, when Ravana was abducting Sita to his kingdom of Lanka, a fierce } \\
\text { battle took place between him and the vulture King Jatayau. The bird was fatally wounded it its attempt } \\
\text { to rescue Sita from Ravana. }\end{array}$ \\
\hline 12 & Columba turica & Dove/Pigeon & $\begin{array}{l}\text { Goddess Rati, the Goddess of passion and lust and the consort of Kama, the God of love, is believed to } \\
\text { be usually depicted with a pigeon as her vahana. }\end{array}$ \\
\hline 13 & Corvus splendens & House Crow & $\begin{array}{l}\text { The house crow occupies a special place in Hindu religious rituals. It is usually identified with departed } \\
\text { souls of ancestors. In Hindu the ritual of 'pinda pradhana' (offering of cooked rice balls) to the crow. }\end{array}$ \\
\hline 14 & Sus scrofa Linnaeus & Wild Boar & $\begin{array}{l}\text { The third avtara of Lord Vishnu was Varaha, a boar. Varaha is generally depicted having a boars head on } \\
\text { human body. Varahi is the Hindu Goddess Durga in the form of a wild boar. }\end{array}$ \\
\hline 15 & Ratufa indica & Squirrel & $\begin{array}{l}\text { Squirrels are considered sacred in India and are not to be harmed. Squirrels are association with Lord } \\
\text { Rama. During the construction of the Adi Sethu (bridge) at Rameshwaram by Lord Rama and the vanara } \\
\text { sena, a little squirrel also contributed in its own little way. Lord Ramas pleased by the creatures } \\
\text { dedication, caressed the squirrels back and ever since, the Indian squirrel carried white stripes on its } \\
\text { back, which are believed to be the mark of Lord Ramas fingers. }\end{array}$ \\
\hline
\end{tabular}

flowers, where different flowers are found in abundance near SGs. Sacred groves are the natural gene pool preserver and example of habitat preservation through community participation (Gadgil and Vartak 1975). Scientific reports also confirm the fact that SGs protect a variety of flora and fauna (Ray and Ramachandra 2010). Sukumaran et al. (2008) highlighted the species richness of 212 miniature sacred groves of Tamil Nadu. Due to this deep rooted religious system, many trees are not axed as they are supposed to increase longevity. In Uttarakhand, Cedrus deodara is treated as a religious tree and worshipped during rituals and religious ceremonies. In Madhya Pradesh, the Gond tribes only use the fallen parts of the tree and cutting this sacred tree is totally prohibited. The neem tree (Azadirachta indica) is considered to be a manifestation of Goddess Durga. Besides, Tulsi plant (Ocimum sanctum) is worshipped as Goddess by women throughout the country which is supposed to enhance the longevity of their husbands' life.

\section{Socio-cultural functions to the sacred groves}

Many rituals are performed in the sanctity of SGs for want of rains, good health of livestock and for fending off any impending disaster. In some parts of Karnataka, people offer miniature images of cattles to keep their livestock's healthy (Kalam 1996). Among the Bhils of Ratanmal, food and liquor are offered to SGs on the occasion of Deepawali a national festival (Nath 1960). Likewise, in West Bengal, social gathering takes place in the vicinity of SGs on the occasion of Salui and Karam festivals (Deb and Malhotra 1997). Different festivals such as Holi, Deepawali, and Navratri are performed around SGs in Ratnagiri district of Maharashtra (Godbole et al. 1998). Similarly, Anthwal et al. (2006) reported several festivals related to SGs in Uttarakhand. Many plants species have also been associated with religious festivals viz: Azadirachta indica (Sheela asthami, Nimb saptami), Ficus bengalensis (Vrat savitiri), Aegle marmelos (Bilvamengal sawan ke somvaar), Musa paradisica (Kadii vrat) and Ficus 
religiosa (Somvari amavasya) due to popular and common beliefs (Table 2).

\section{Threats to the sacred groves}

SGs are showing sign of weakening and decrease in terms of cultural, biological and ecological integrity in different states of the country. The number of SGs in different states also depends upon the magnitude of these threats which is area specific (Table 3). Over the past few decades many people have lost their rights of forest management to the government. Many scholars have worked on conservation of sacred groves through socio-cultural practices in different parts of India (Gadgil and Vartak 1975; Boojh and Ramakrishnan 1983; Khiewtam and Ramakrishnan
1989; Rodgers 1994; King-Oliver et al. 1997; Tiwari et al. 1998; Sinha and Maikhuri 1998; Sunitha and Rao 1999; Basu 2000; Kushalapa et al. 2001; Bhagwat et al. 2005; Jaryan et al. 2010; Kala and Sharma 2010; Anthwal et al. 2010). There are several reasons for this decrease in terms of area and number, primary being lack of documentation as a result of which it becomes difficult to conserve and maintain them. No legislative protection has been implemented so far in India.

Lack of awareness in terms of long term future benefits has also resulted in the destruction of SGs. Various religious beliefs, influx of large number of pilgrims and tourists and conversion to other religions axing of plants for monetary benefit have contributed consistently for

Table 2 List of some sacred plants in Hindu mythology

\begin{tabular}{|c|c|c|c|c|}
\hline S. No. & Scientific name & Local name & Family & Beliefs/uses \\
\hline 1 & Aegle marmelos (L.) Corr. & Bail & Rutaceae & Ritual/medicine/sacred \\
\hline 2 & Artemisia nilgirica (Clarke) & Kunju & Compositae & Ritual \\
\hline 3 & Atrocarpus heterophyllus Lamk. & Theibong & Moraceae & Ritual \\
\hline 4 & Azadirachta indica & Neem & Meliaceae & Ritual/medicinal \\
\hline 5 & Blumea balsamifera (L.) DC. & Bari ilaichi & Compositae & Ritual/medicine \\
\hline 6 & Betula utilis & Bhoj patra & Betulaceae & Ritual/sacred \\
\hline 7 & Calotropis procera (Ait.) R. Br. & Aak & Asclepiadaceae & Rituals \\
\hline 8 & Cedrus deodara & Deodar & Pinaceae & Sacred \\
\hline 9 & Cynodon dactylon Pers. & Dhoob & Poaceae & Ritual \\
\hline 10 & Datura stramonium & Datura & Solanaceae & Ritual/medicinal \\
\hline 11 & Desmostachya bipinnata & Kush & Gramineae & Ritual \\
\hline 12 & Elaeocarpus Ganitrus Roxb. & Rudraksha & Eleocarpaceae & Sacred/Ritual \\
\hline 13 & Emblica officinalis & Amla & Phyllanthaceae & Sacred/medicinal \\
\hline 14 & Erythrina indica Lam. & Paribhadraka & Faboideae & Ritual \\
\hline 15 & Ficus benghalensis & Bargad & Moraceae & Ritual/sacred \\
\hline 16 & Ficus religiosa & Peepal & Moraceae & Sacred \\
\hline 17 & Mangifera indica L. & Mango & Anacardiaceae & Ritual \\
\hline 18 & Musa paradisica & Banana & Musaceae & Ritual \\
\hline 19 & Ocimum sanctum L. & Tulsi & Lamiaceae & Sacred/medicinal \\
\hline 20 & Pinus roxburghii & Chir & Pinaceae & Ritual \\
\hline 21 & Princepia utilis & Bhakel & Rosaceae & Ritual \\
\hline 22 & Prosopis cineraria & Khachri & Leguminosae & Rituals \\
\hline 23 & Prunus cerasoides & Paiya & Rosaceae & Rituals \\
\hline 24 & Punica granatum & Daru & Lythraceae & Ritual \\
\hline 25 & Santalum album & Sandal & Santalaceae & Ritual \\
\hline 26 & Saussurea obvallata & BramKamal & Asteraceae & Sacred \\
\hline 27 & Terminalia arjuna (Roxb.) & Arjun & Combretaceae & Ritual/medicine \\
\hline 28 & Toona ciliata M. Roem. & Tun & Meliaceae & Ritual \\
\hline 29 & Xanthoxylum achanothopodum & Timoor & Rutaceae & Sacred/Rituals/medicine \\
\hline 30 & Zanthoxylum armatum & Timoor & Rutaceae & Ritual/medicine \\
\hline 31 & Quercus leucotrichophora & Oak & Fagaceae & Sacred \\
\hline
\end{tabular}


Table 3 Total Sacred groves distribution in India (Adopted from Malhotra, 1998 and Malhotra et al., 2001)

\begin{tabular}{|c|c|c|c|c|}
\hline Sr. No & State & Number of SGs & Generic name & Reference \\
\hline 1 & Andhra Pradesh & 750 & * & WWF (World Wildlife Fund) Andhra Pradesh (1996) \\
\hline 2 & West Bengal & 670 & Bankura & Deb et al. (1997) \\
\hline 3 & Uttaranchal & 1 & Bugyal, Devban & \\
\hline 4 & Tamil Nadu & 448 & Kovilkadu/ Nandavana & Amrithalingam, 1998 \\
\hline 5 & Sikkim & 56 & Gumpa forest area & Chatterjee et al. 2000 \\
\hline 6 & Rajasthan & 9 & Orans Kenkris & Jha et al. 1998 \\
\hline 7 & Orissa & 322 & Jahera/Thakuramma & Malhotra and Das 1997 \\
\hline 8 & Meghalaya & 79 & Ka Law Kyntang & Tiwari et al. 1998 \\
\hline 9 & Manipur & 365 & Gamkhap, Umanglai & Devi, 2000; Khumbongmayum et al. 2004 \\
\hline 10 & Maharashtra & 1600 & Devrai, Devrahati & Deshmukh et al. 1998 \\
\hline 11 & Kerala & 2000 & Sarpakkavu/Nagavanam & Rajendraprasad 1996 \\
\hline 12 & Karnataka & 1214 & Devarabana/ Sidharavanam & Kalam 1996 \\
\hline 13 & Jharkhand & 21 & Sarana/Jaherthan & \\
\hline 14 & Chhattisgarh & 2000 & Devgude, Malgudi & \\
\hline 15 & Gujarat & 29 & * & Gupta et al. 2000 \\
\hline 16 & Haryana & 248 & * & NAEB National Afforestation and Eco-development Board 1995 \\
\hline 17 & Himachal Pradesh & 5000 & Dev ban & Sharma 2000 \\
\hline 18 & Assam & 40 & Miadaico & Deb et al. 1997 \\
\hline 19 & Arunachal Pradesh & 58 & Gumpa Forest & Chatterjee et al. 2000 \\
\hline Total & & 13720 & & \\
\hline
\end{tabular}

*Generic names are unavailable.

the degradation of these well flourished areas of vegetation to a mere crunch of trees in many parts of India. Greed for certain plants like sandal (Santalum album) has resulted in decrease of their numbers in India and particularly in Himalayan SGs. The indigenous species found in the sacred groves are threatened by the introduction of exotic weeds such as Common Floss flower (Eupatorium odoratum), Shrub verbenas (Verbena officinalis), Lantana (Lantana camara) and Parthenium (Parthenium hysterophorus) etc. Likewise, grazing, lopping and removal of biomass have also resulted in dwindling of the groves. Encroachments of SGs areas by local communities or various other government departments, migration and immigration of people have contributed to the extinction of SGs. The most recent threat to SGs is witnessed from the process of modernization, industrialization, greed of land mafias and construction of building structures resulting is loss of cultural and ecological importance among the younger generation of local people.

For providing necessary protection to the SGs and maintain their natural identity and sanctity it is imperative that cooperation of the people is extended. The surrounding village communities need to be educated and guided for sustaining the sanctity of existing grove and strengthening them. Legislation by the state government against cutting of such important trees need to be in place as is existing against cutting of khair (Acacia catechu) in state of Himachal Pradesh, where severe punishment is awarded for violation of the directions. During contact with woman in the villages adjoining different SGs, it was felt that they were more enthusiastic regarding conservation and preservation of different plants. Their concern was of rapid loss of important plants of utility in recent years and felt that the following issues need to be addressed without fail (Table 4).

\section{Conclusion}

In the words of Dr. M.S. Swaminathan, "Unlike a botanical garden, where a wide range of trees and plants are collected and cultivated for the purpose of our education and enjoyment, the sacred groves are one method of

\section{Table 4 Issues concerns for SGs conservations}

\begin{tabular}{ll}
\hline S. No & Concerns for conservation \\
1 & $\begin{array}{l}\text { Capacity building of woman regarding importance of SGs land } \\
\text { planting by forest department for immediate multiplication of } \\
\text { such plants for release in different villages } \\
\text { Appointing contact persons in villages on monthly basis if not on } \\
\text { regular basis as in case of water carriers in school for maintenance } \\
\text { of identified SGs specially near village and place of worship. }\end{array}$ \\
3 & $\begin{array}{l}\text { Involvement of school children for creating awareness and } \\
\text { augmentation of SGs }\end{array}$ \\
5 & Regular visits by forest staff for guidance and maintenance of SGs. \\
\hline
\end{tabular}


expressing the gratitude of human beings to the trees which sustain and support life under a given agroecological condition". We therefore need immediate measures to stop the destruction of SGs and start their conservation as being an integral part of the social and cultural life in rural India. Documentation of all the sacred groves needs to be taken up on high priority basis so that management and conservation programs for these threatened groves can be initiated. The bondage between people, their beliefs and rituals associated with SGs in the past have hidden scientific truth. Many ancient trees are surviving till date due to the sacred belief and worship. However, in the past heavy inflow of tourists around sacred groves, threatened their very existence. Loss in faith and religious conversions in general has further intensified the magnitude of erosion of beliefs and value system. Hence, revival of SGs institution for the conservation of valuable biodiversity and ecosystem services is necessary. At the same time the cultural, biological, social and ecological importance of SGs cannot be ignored. Therefore, there is a great need for restoration and management of SGs to preserve scientific ecological system. A scientific understanding of harmony and co-existence of flora and fauna will strengthen the importance of SGs and play an important role in designing strategies for their rehabilitation and management for maintenance of sustainable ecological balance. Awareness building regarding the importance of sacred groves is first and foremost step needed to be taken for the revitalization of these traditional values, practices and beliefs among the youth. Benefit sharing should be promoted within the local communities for conserving and maintaining the groves. Stringent legislation followed by punishment accordingly is definitely needed for long and healthy life of sacred groves and therefore conservation as a whole.

\section{Some positive signs}

- The Social Forestry wing of the Kerala Forest Department has signed memorandums of association with the owners of select groves for protection, enhancement of biodiversity and awareness programmes and 15 sacred groves have received assistance for their conservation efforts (The Hindu, May 5, 2013, India)

- Chilkigarh a sacred grove being located almost in trijunction of the three states (West Bengal, Bihar and Orissa) is known for its rich and unique floral wealth was indiscriminately exploited earlier and presently the entire sacred complex has been taken over by the local Kanak Durga Temple trust consisting of members from Chilkigarh and adjoining villages. They have revived the concept of social fencing through inculcating the traditional socio-religious and ecological values of plants and simultaneously getting economic benefits through the tourists, visitors and devotees.

\section{Methods}

A good number of SGs are found scattered in the hills of Garhwal and Kumaon region (Uttarakhand) India near the bank of rivers, Bhagirathi, Mandakani, Alaknanda as well as in the world famous spiritual centers of Yamunotri, Gangotri, Kedarnath and Badrinath. The places are visited by pilgrims in thousands, throughout the year. To collect information for the present study, a small team was constituted to visit such areas with a prepared questionnaire on different type of plants, utilized by people in adjoining villages, extinct plants and their use for religious ceremonies and awareness of these plants as well as common animals \& birds attached to associated beliefs. Ten centers each were visited in the areas of Uttarkashi, Pauri, Tehri and Chamoli for this purpose. Necessary information was collected from five people in each centre majority of whom were functioning priests serving in the area. Thus, a total of 200 people were contacted for their views on the present status of the SGs. The information was later complied and tabulated.

\section{Competing interests}

The authors declare that they have no competing interests.

\section{Authors' contributions}

LSK contributed in the experiment design, data collection and manuscript writing and editing. VKB, MB and AKT helps in manuscript writing and data collection. All authors read and approved the final manuscript.

\section{Acknowledgements}

Authors are thankful to Haramaya University, Dire-Dawa, Ethiopia for providing necessary facilities. Contribution and help from traditional medicine practioners (Vaidyas) and other local healers of the study area in India are hereby

acknowledged.

\section{Author details}

${ }^{1}$ School of Natural Resource Management and Environmental Sciences, College of Agriculture and Environmental Sciences, Haramaya University, P.O. Box \# 337, Dire Dawa, Ethiopia. ${ }^{2}$ Herbal Research and Development Institute, Gopeshwar, Chamoli, Uttarakhand, India. ${ }^{3}$ Protection of Plant varieties and Farmers' Right Authority, NASC Complex, DPS Marg, New Delhi, India.

${ }^{4}$ School of Plant Sciences, College of Agriculture and Environmental Sciences, Haramaya University, P.O. Box \# 138, Dire Dawa, Ethiopia.

Received: 19 February 2014 Accepted: 24 April 2014

Published: 20 June 2014

\section{References}

Amrithalingam M (1998) Sthala Vrikshas of Tamil Nadu. In: Krishna N, Prabhakaran J (eds) The Ecological Traditions of Tamil Nadu. C.P.R. Environment Education Centre, Chennai

Anthwal A, Sharma RC, Sharma A (2006) Sacred groves: Traditional way to conserving plant diversity in Garhwal Himalaya, Uttaranchal. The J Am Sci 2(2):35-43

Anthwal A, Gupta N, Sharma A, Anthwal S, Kim KH (2010) Conserving biodiversity through traditional beliefs in sacred groves in Uttarakhand Himalaya, India. Resour Conserv Recy 54:962-997

Banjo AD, Otufale GA, Abatan OL, Banjo EA (2006) Taboo as a means of plant and animal conservation in South-Western Nigeria: a case study of Ogbe River and its basin. World Appl Sci J 1:39-43 
Basu R (2000) Studies on sacred groves and taboos in purulia district of west Bengal. Indian For 1:309-1317

Bhagwat SA (2009) Ecosystem services and sacred natural sites: reconciling material and non-material values in nature conservation. Environ Values 18:417-427

Bhagwat SA, Kushalappa CG, Williams PH, Brown ND (2005) A landscape approach to biodiversity conservation of sacred groves in the western Ghats of India. Conserv Biol 19:1853-1862

Bhandary MJ, Chandrasekhar KR (2003) Sacred groves of dakshina kanada and udupi districts of Karnataka. Curr Sci 85:655-1656

Boojh R, Ramakrishnan PS (1983). In: Strategies for Environmental Management, Souvenir Vol. Dept. of Science and Environmental of Uttar Pradesh, Lucknow, pp 6-8

Cardelús CL, Scull P, Hair J, Baimas-George M, Lowman MD, Eshet AW (2013) A preliminary assessment of Ethiopian sacred grove status at the landscape and ecosystem scales. Divers 5:320-334

Chandran MDS, Gadgil M, Hugues JD (1998) Sacred groves of the Western Ghats of India. In: Ramakrishnan PS, Saxena KG, Chandrashekar UM (eds) Conserving the Sacred for Biodiversity Management. Oxford and IBH Publishing Co.Pvt Ltd, New Delhi

Chatterjee S, Sastry ARK, Roy BN, Lahon R (2000) Sacred groves of Sikkim and Arunachal Pradesh. Abstract. National Workshop on Community Strategies on the Management of Natural Resources, Bhopal

Colding J, Folke C (1997) The relations among threatened species, their protection, and taboos. Conserv Ecol 1:1-6

Deb D, Malhotra KC (1997) Interface between biodiversity and tribal cultural heritage: an exploratory study. J Hum Ecol 8:157-163

Deb D, Deuti K, Malhotra KC (1997) Sacred grove relics as bird refugia. Curr Sci 73:815417

Deshmukh S, Gogate MG, Gupta AK (1998) Sacred groves and biological diversity: providing new dimensions to conservation issue. In: Ramakrishnan PS, Saxena KG, Chandrashekhara UM (eds) Conserving the Sacred for Biodiversity Management. Oxford and IBH, New Delhi, pp 397-414

Devi S (2000) Sacred groves of Manipur. Abstract. National Workshop on Community Strategies on the Management of Natural Resources, Bhopal

Forest Policy (1988) http://envfor.nic.in/nfap/detailed-policy.html

FSI (Forest Survey of India) (2005) State of Forest Report 2005. Forest Survey of India, Government of India, Dehradun, India

Gadgil M, Vartak D (1975) Sacred groves of India- a plea for continued conservation. J Bombay Natu Hist Soc 72:313-320

Godbole A, Watv A, Prabhu S, Sarnaik J (1998) Role of sacred groves in biodiversity conservation with 1ocal people's participation: A case.study from Ratnagiri district, Maharashtra. In: Ramakrishnan PS, Saxena KG, Chandrashekara UM (eds) Conserving the Sacred for Biodiversity Management. Oxford and IBH Publishing Co., New Delhi, pp 233-246

Gupta A, Shukla S, Koradiya D, Bhavsar P, Ramji A, Patel P, Taviyad R (2000) A cultural and ecological study of sacred groves in Balaram Ambaji and Jessore sanctuary in Banaskantha district of Gujarat. Abstract. National Workshop on Community Strategies on the Management of Natural Resources, Bhopal

Hangarge LM, Kulkarni DK, Gaikwad VB, Mahajan DM, Chaudhari N (2012) Carbon Sequestration potential of tree species in Somjaichi Rai (Sacred grove) at Nandghur village, in Bhor region of Pune District, Maharashtra State, India. Ann Biol Res 3(7):3426-3429

Hughes DJ, Chandran SMD (1997) Paper Presented in the Workshop on the Role of Sacred Groves in Conservation and Management of Biological Resources. KFRI, Peechi

Jaryan V, Uniyal Gopichand SK, Singh RD, Lal B, Kumar A, Sharma V (2010) Role of traditional conservation practice: highlighting the importance of Shivbari sacred grove in biodiversity conservation. Environmentalist 30:101-110

Jha M, Vardhan H, Chatterjee S, Kumar K, Sastry ARK (1998) Status of Orans (Sacred groves) in Peepasar and Khejarli villages in Rajasthan. In: Ramakrishnan PS, Saxena KG, Chandrashekara UM (eds) Conserving the Sacred for Biodiversity Management. UNESCO and Oxford IBH Publishing, New Delhi, pp 263-275

Kala M, Sharma A (2010) Traditional Indian beliefs: a key towards sustainable living. Environmentalist 30:85-89

Kalam MA (1996) Sacred Groves in Kodagu District of Karnataka (South India): A Socio-Historical Study. Institute Francais de Pondicherry, Pondicherry, India

Khan ML, Tripathi RS (2004) Sacred groves of Manipur- ideal centers for biodiversity conservation. Curr Sci 87(4):430-433
Khiewtam RS, Ramakrishnan PS (1989) Socio-cultural studies at the sacred groves at Cherrapunji and adjoining areas in north-eastern India. Man India 69(1):64-71

Khumbongmayum AD, Khan ML, Tripathi RS (2004) Sacred groves of Manipur: ideal centres for biodiversity conservation. Curr Sci 87(4):430-433

King-Oliver IED, Chitra V, Narasimha D (1997) Sacred groves: traditional ecological heritage. Int J Ecol Environ Sci 23:463-470

Kushalapa CG, Bhagwat SA, Kushalapa KA (2001) Conservation and management of sacred groves of Hodagu, Karnataka, South India-a unique approach. In: Ganeshaiah KN, Shaanker UR, Bawa KS (eds) Tropical Ecosystems: Structure. Diversity and Human Welfare. Oxford IBH Publishing Co. Pvt. Ltd, New Delhi, pp 565-569

Malhotra KC (1998) Anthropological dimensions of sacred groves in India: An overview. In: Ramakrishnan PS, Saxena KG, Chandrashekhara UM (eds) Conserving the Sacred for Biodiversity Management. Oxford and IBH Publishing Co. Pvt. Ltd., pp 423-438

Malhotra KC, Das K (1997) Interface between faunal biodiversity and cultural heritage in south-west Bengal, in India. In: Fujiki N, Macer RJ (eds) Bioethics in Asia. Eubois Ethics Institute, Japan, pp 346-351

Malhotra KC, Gokhale Y, Chatterjee S, Srivastava S (2001) Cultural and Ecological Dimensions of Sacred Groves in India. Indian National Science Academy, Indira Gandhi Rashtriya Manav Sangrahalaya, New Delhi, Bhopal, p 30

Malhotra KC, Gokhale Y, Chatterjee S, Srivastava S (2007) Sacred Groves in India. Aryan Books International, New Delhi, India

Manikandan P, Venkatash DR, Muthuchelian K (2011) Conservation and management of sacred groves in theni district, Tamil Nadu, India. J Biosc Res 2(2):76-80

Meenakshi B, Chauhan NS, Kak A (2011) Dye yielding plants of Himachal Pradesh. J Econo Taxon Bot 35(2):429-432

Myers N, Mittermeir RA, Mittermeir CG, da Fonseca GAB, Kents J (2000) Biodiversity hotspots for conservation priorities. Nature 403:853-858

NAEB (National Afforestation and Eco-development Board) (1995) Sacred groves of Kurukshetra, Haryana. National Afforestation and Ecodevelopment Board, Ministry of Environment and Forests. Govt. 'of India, New Delhi India

Nath WS (1960) Bhils of Ratanmal, Maharaja Sayajirao University. Baroda. Oxford and IBH Publishing Co., New Delhi, pp 289-300

Negi CS (2005) Religion and biodiversity conservation: not a mere analogy. Int J Biodiv Sci Manage 1:85-96

Pal T, Mukhopadhyay M (2011) Change in Socio-cultural dimensions and its impact on exiting Sacred grove. Int J Human Soc Sci 1(10):242-250

Pandey DN (2003) Sacred Forest: The Case of Rajasthan. India in Forest Service, India, pp 1-16

Pandit PK, Bhakat RK (2007) Conservation of biodiversity and ethnic culture through sacred groves in Midnapore district, West Bengal, India. Indian For 133:323-344

Rajendraprasad M (1996) The Floristic, Structural and Functional Analysis of Sacred Groves of Kerala. Ph.D Thesis. University of Kerala, Thiriuvanthapuram, India

Ramakrishnan PS (1996) Conserving the sacred from the species to landscape. Nat Resour 32:11-19, UNESCO

Ray R, Ramachandra TV (2010) Small sacred groves in local landscape: are they really for conservation. Curr Sci 98(9):1178-1180

Rehmani C (2012) Rural India, the emerging growth centre for Indian retailers. Indian Streams Res J 2(11):1-3

Rodgers WA (1994) The sacred groves of Meghalaya. Man India 74:339-348

Sharma BR (2000) Sacred groves and their role in social life in Himachal Himalayas. Abstract National Workshops on Community Strategies on the Management of Natural Resources. Bhopal, India

Singh H, Husain T, Agnihotri P (2010) Haat kali sacred grove, Central Himalaya, Uttarakhand. Curr Sci 98(3):290

Sinha B, Maikhuri RK (1998) Conservation through socio-cultural- religious practices in Garhwal Himalayas: A case study of Hariyali sacred forest. In: Ramakrishnan PS, Saxena KG, Chandrashekara UM (eds). Conserving the Sacred for Biodiversity Management

Sukumaran S, Jeeva S (2008) A floristic study on miniature sacred forests at Agastheeshwaram, southern peninsular India. Eur Asian J Biosci 2:66-78

Sukumaran S, Jeeva S, Raj ADS, Kannan D (2008) Floristic diversity, conservation status and economic value of miniature sacred groves in Kanyakumari district, Tamil Nadu, Southern Peninsular India. Turkish J Bot 32:185-199

Sunitha S, Rao RPB (1999) Sacred groves in Kurnool District, Andhra Pradesh. In: Sivadasan M, Mathew P (eds) Biodiversity, Taxonomy and Conservation of Flowering Plants. Mentor books, Calicut, pp 367-373 
Tiwari BK, Barik SK, Tripathi RS (1998) Sacred groves of Meghalaya. In: Ramakrishnan PS et al (eds) Conserving the Sacred for Biodiversity Management. Oxford \& IBH Publishing Co., New Delhi, India, pp 253-262

Vartak VD, Kumbhojkar MS, Nipuge DS (1987) Sacred groves in tribal areas of

Western Ghats: treasure trove of medicinal plants. B Medi Ethno Bot Res 8:77-78

WWF (World Wildlife Fund) Andhra Pradesh (1996) Sacred Groves of Andhra Pradesh. World Wide Fund for Nature. Andhra Pradesh state Office,

Hyderabad

doi:10.1186/s40068-014-0016-8

Cite this article as: Kandari et al:: Conservation and management of sacred groves, myths and beliefs of tribal communities: a case study from north-India. Environmental Systems Research 2014 3:16.

Submit your manuscript to a SpringerOpen ${ }^{\circ}$ journal and benefit from:

- Convenient online submission

- Rigorous peer review

- Immediate publication on acceptance

- Open access: articles freely available online

- High visibility within the field

- Retaining the copyright to your article

Submit your next manuscript at $\gg$ springeropen.com 